\title{
COMMON FISHERIES POLICY AND ITS IMPACT ON THE FISHERIES SECTOR IN CROATIA
}

\section{Ornella Mikuš*, Magdalena Zrakić, Tihana Kovačićek, Mateja Jež Rogelj}

University of Zagreb Faculty of Agriculture, Department of Agricultural Economics and Rural Development, Svetošimunska 25, Zagreb, Croatia

*Corresponding Author, Email: omikus@agr.hr

\section{ARTICLE INFO}

Received: 31 October 2017

Received in revised form: 6 December 2017

Accepted: 15 December 2017

Available online: 29 January 2018
Keywords:

Croatia

EU

Fisheries policy

Fisheries budget

Macroeconomic indicators

\begin{abstract}
The aim of the paper is: 1) to determine the key changes in the evolution process of the EU Common Fisheries Policy (CFP) and the Croatia's fisheries policy and 2) to describe the structure and dynamics of macroeconomic and budget performance related to Croatian fisheries in the period 20072016. Two methods were used: the historical method and the descriptive analysis of macroeconomic performance and budget structure. The CFP was officially introduced in 1983, bringing the management of fisheries in all EU member states under one system. Its aims were: to resolve sea conflicts between member states, to provide stability to the fisheries sector, to prevent a total collapse of fish stocks and to provide higher quality of life to the fishermen. However, the CFP has constantly been criticized for poor enforcement of environmental measures and scientific recommendations, and for the lack of a common language between the EU institutions and local stakeholders. Both the European and Croatian fisheries sector faced many problems, especially during the transition period in the 1990s. Some of them included a serious decrease of catches, outdated technology and fisheries fleet, depletion of demersal species, lack of developmental trends in mariculture, absence of measures of rational exploitation and protection of economically significant species. The negotiation period was an opportunity for the fisheries sector in Croatia to adapt its goals, measures and stakeholders in order to achieve a more sustainable and internationally competitive fisheries sector in the future. The membership facilitates trade in the EU area, along with providing significant funding and technical assistance. The budget support structure and the existing policy framework point out an increase in the implementation of structural measures which should assist in an overall improvement of social, economic and environmental aspects of fisheries.
\end{abstract}

Mikuš, O., Zrakić, M., Kovačićek, T., Jež Rogelj, M. (2018): Common Fisheries Policy and its impact on the fisheries sector in Croatia. Croatian Journal of Fisheries, 76, 41-50. DOI: 10.2478/cjf-2018-0005. 


\section{INTRODUCTION}

The origins of the Common Fisheries Policy (CFP) can be found in the Treaty of Rome (EC, 1957), the document by which the European Economic Community was established. The main focus of the Treaty was to form a common market of goods coming from six founding member states (Belgium, Netherlands, Luxembourg, Italy, France and West Germany) which agreed to gradually abolish all tariff barriers and organize a common market. The common organization of the market referred to a combination of legal institutions and measures by which appropriate authorities control and regulate the market (Churchill, 1987). The inclusion of fisheries within the common market meant that member states could trade more easily among one another, but the actual fishing rights were not attended to until the European Fisheries Convention in 1964 (Walter, 2010). The CFP was first enacted in 1983 and has undergone several major changes and reforms through history. Sustainable use of fisheries resources is a constant source of debate, and the allocation of these resources is one of the most difficult issues for the stakeholders to agree upon. Until 1965, the Croatia's fisheries policy consisted mainly of inefficient and periodical input support. Little or no attention was given to balanced and long-term sustainable fishing. During the 1990s, the fisheries sector experienced elements of transition from centralized to market-planned economy, which caused a decrease in production and structural issues. The negotiation period for the EU membership was an opportunity for Croatia to adjust its fisheries policy to the CFP framework which insists on the protection of natural resources, aquaculture support and cessation aimed to prevent overexploitation of fishing grounds. As a EU member state, Croatia could provide additional funds to improve the physical infrastructure, market organization and socio-economic performance in fisheries. The first part of the paper examines the highlights of CFP reforms, as well as the process of adaptation to enlargements and conflicts of biological, environmental and socio-economic considerations. The second part of the paper deals with the position of fisheries in Croatia before and within the CFP, along with their macroeconomic performance. For the first time, the existing scientific and expert discourse will be enriched with an analysis of the budget structure change for the ten-year period (2007-2016). It is expected that the share of both market-price and structural support in fisheries will adapt to the new requirements of the CFP. The aim of the paper is: 1) to determine the main elements of change in the evolution process of the EU Common Fisheries Policy and the Croatia's fisheries policy and 2) to describe the structure and dynamics of macroeconomic and budget performance related to the Croatian fisheries in the period 2007-2016.

\section{MATERIALS AND METHODS}

For the purpose of this paper, a qualitative analysis of scientific and administrative resources dealing with the CFP will be conducted using the historical method. The present state of the CFP is a consequence of specific historical circumstances which involve enlargement processes and continuous disputes among member states over who should be allowed to fish, what, where, how and how much. A short history and position of Croatia in regard to the fisheries policy will be examined through national fisheries documents and scientific papers. Descriptions of the fisheries sector and policy within the Yugoslavian regulatory frame could mainly be found in graduation theses. The sources of macroeconomic indicators are the Croatian Bureau of Statistics (CBS), Eurostat and Ministry of Agriculture (MA) Directorate of Fisheries (DF), while the sources of data on budget support are the Ministry of Finance (MF) and the Paying Agency for Agriculture, Fisheries and Rural Development (PAAFRD). The analysis of budget support for fisheries purposes includes both the EU and national budget, and provides a deeper insight into its structure during the period 2007-2016.

\section{Historical background of the Common Fisheries Policy}

Until 1977, the European Community Fisheries Policy aimed to increase the insufficient fish supply on the common market. Until 1970, the fisheries policy did not entail a separate legal basis which would prevent inherent misunderstandings among European countries relating to access conditions to maritime waters and over-utilization of resources. The fisheries were merely another agricultural sector and their policy objectives were related to the Common Agricultural Policy objectives defined in the Treaty of Rome: productivity increase, fair standard of living for the agricultural community, stabilization of markets, viability of supplies and reasonable prices. Attempts to apply those objectives to the fisheries sector resulted in considerable difficulties: increase in productivity, technical progress and assurance of supplies led to the over-exploitation of fish and lack of proper conservation measures (Churchill, 1987). Before the first CFP, market access and organization, subsidies and resource management were all regulated by different systems in member states. For example, France and Italy's conservative position on a pro-subsidies system was opposed to Germany and the Netherlands' liberal, laissez-faire system in their competitive fisheries sectors. Germany feared that it would have to financially contribute the most to the policy, but would profit the least from it. The first Community legislative, the Fisheries Act, was adopted in 1970 (OJ 2141/70). According to the Act, the fisheries policy consisted of market and structural policies 
which subsidized the fishing industry by ensuring minimum prices of fish and providing grants for vessel construction to ensure a more lucrative yield. The fisheries in Europe were a sector of regulated open access where the Community shared harvest places with other countries in Europe. Six member states agreed that fishing vessels belonging to member states would have free and equal access to the waters belonging to all other members. This was the most controversial agreement which applied the principle of nondiscrimination on the grounds of nationality among member states. Their main argument was that fish is a common good and that member states should have common conservation management (Schweiger, 2010). Open access and common right over fish resources became the main reasons of conflict between member states. The first EU enlargement was about to happen in 1970s; the negotiation process for Denmark, Ireland, Norway and the United Kingdom started on 30 June 1970 and on the same day the agreement on the first Common Fisheries Policy was reached. Future member states saw the equal access rule as a threat to their domestic fisheries. This policy was one of the reasons why Norway did not join the EU. Due to the adverse impact on the fishing industry, Iceland withdrew the application to join the EU in 2013 , which stands as yet another proof of the seriousness of conflict (Schweiger, 2010).

\section{Common Fisheries Policy enforcement and the first reform in 1993}

The CFP was introduced in 1983, bringing the management of fisheries under a single system (Symes, 1997). Its major achievement was the recognition of conservation to which a significant role was attributed in the CFP. The conservation policy was supplemented with structural measures and a control system (Lynge, 1999). The CFP was created on the basis of four pillars (Surís-Regueiro et al., 2011): 1) Market Policy, establishing the regulations for marketing fish and a system whereby minimum sale prices for fish products are sustained, 2) Structural Policy, aimed to improve the competitiveness and sustainability of the fishing industry, mostly by infrastructure modernization, 3) Resource Policy (conservation), which establishes the regulations to protect natural fisheries resources and 4) External Relations Policy, responsible for international fishing agreements. Under the EU Common Fisheries Policy, the sea within 6 miles off the coast was reserved for the coastal states' fishermen. Between 6 and 12 miles off the coast, access was allowed only to fishermen from the countries that traditionally fished in that area. Between 12 and 200 miles off the coast, access was generally allowed to fishermen from any EU country, with a few exceptions. Regulation operated via quotas and effort control (Barclay, 1996). Total Allowable Catch (TAC) was divided into quotas for each fishing member state according to the proportion of history catches before the CFP came into force. Spain and Portugal (Iberian countries) had a significant effect on the CFP during the third enlargement in 1986. Their accession brought significant increases in the fishing sector, production of fish and shellfish and fish consumption. The main problem was the large size of the Iberian fishing fleet which was a threat to the existing member states in the TAC system where quotas could be downsized for member states in order to be allocated to Spain or Portugal. Negotiations in this field were especially demanding, resulting in limited Iberian access to the member states' waters until 2002, with possible adjustments in 1996 (Churchill, 1987). In the 1990s, there was a substantial public pressure, criticism from environmental activists and scientific concern regarding the need for additional efforts to stop the decline of fish stocks. The European Commission recognized the failure of the CFP and called for the need to adapt the fishing fleet to available natural resources (Surís-Regueiro et al., 2011). The discussion resulted in the first CFP reform in 1993 as a framework to reduce the Community fleet considering the social impact by means of structural measures. Additionally, the Financial Instrument for Fisheries Guidance (FIFG) was created as an instrument to implement the measures related to the adjustment of fishing effort, fleet modernization, processing and marketing of fish products, as well as to aid regional development.

\section{Reforms of the Common Fisheries Policy FP in 2003 and 2013}

The previous CFP reform measures were not effective enough to significantly reduce overfishing, and the depletion of many fish stocks continued. In 2001, the European Commission (EC) published the Green Paper on the Future of the Common Fisheries Policy (EC, 2001) in which it described the particularly serious situation of fishing stocks being outside safe biological limits. At the same time the available fishing capacity of the Community fleets far exceeded the requirements for harvesting fish in a sustainable manner. The Commission noted that the results of the previous CFP were poor enforcement of quotas, conservation measures to protect stocks, control measures of output and input in fisheries, weak involvement of stakeholders in the decisionmaking process, weaknesses in scientific recommendations and decline of fisheries employment. However, some positive effects were also achieved: containing conflicts at sea, providing a certain degree of stability to the fisheries sector and avoiding the complete collapse of stocks, occasionally witnessed by some areas of the world (EC, 2001). Considering the grave inadequacy of the CFP, the next reform was claimed to be a radical overhaul of the existing framework. Moreover, the pre-2002 CFP was marked by the majority of member states as top-down, bureaucratic, complex, remote, centralized and authoritative (Gray and Hatchard, 2003). The critical situation led to a 
major reform which entered into force at the beginning of 2003. The primary objective of the 2002 reform was to ensure a sustainable future for the fisheries sector by guaranteeing stable incomes and jobs for fishermen and supplying consumers, while preserving the fragile balance of marine ecosystems (Committee on Fisheries Secretariat, 2009). A significant feature of the policy reform was a new legislative framework which allowed the member states a severer penalization of unauthorized maritime actions which jeopardized fishing stocks. Moreover, the new CFP reform announced the involvement of fishermen, scientists, regional and national authorities, environmental groups and consumers in creating and implementing measures. Once again, the CFP reform did not respond to biological or socio-economic requirements and it brought forward an additional problem of discards. The European Commission expressed its critique by identifying the main structural failures as follows (Markus, 2010): 1) fleet overcapacity, 2) imprecise policy objectives resulting in insufficient guidance for decisions, 3) short-term focus, 4) insufficient responsibility for the industry and 5) poor compliance. By now it was fairly obvious that the current public financial support system is incompatible with the CFP objective to reduce capacities which led to overfishing. It induced investments in the fishing industry by reducing production costs and risks, and failed to support the socio-economic consequences of management changes, environmentally friendly actions, scientific research or innovation. Member states were allowed to provide state aid to their fisheries sector which also contributed to overcapacity. Public consultation on the next reform of the CFP started in 2009. Its intended purpose was to generate new principles of EU fisheries which would deal with marine issues of the $21 \mathrm{st}$ century. According to Caddy (1998) some of those are: climate warming, consumer controls, sustainable fisheries development, restoring habitats, maintaining biodiversity, avoiding marine monopolies. After a lengthy debate in May 2013, an agreement on the new CFP was reached. At the moment the CFP includes four main policy areas: 1) Fisheries management, 2) International policy, 3) Market and trade policy and 4) Funding. The European Fisheries Fund became the European Maritime and Fisheries Fund which represents a turning point towards the Integrated Maritime Policy. Priorities for funding are to promote sustainable, resource efficient, innovative, competitive and knowledge-based fisheries, to foster sustainable, resource efficient, innovative, competitive and knowledge-based aquaculture, to foster the implementation of the CFP, to increase employment and territorial cohesion, to foster marketing and processing, to foster the implementation of the Integrated Maritime Policy. Above all, a major turnaround can be seen in the complexity of the new rules, which is the exact opposite of the public requirements - that the CFP needs to be less bureaucratic and complex. An interesting analysis is provided by Pastoors
(2014): The results show a strong increase in the number of words used to describe the basic regulation of the CFP from 3500 words in 1983 to 21,000 words in the agreed regulation in 2013 (...) First reports on the new CFP have already shown that the complexity in the regulation could increase the likelihood of misunderstanding and suboptimal decisions. Unfortunately, the CFP did not meet the expectations of our and future generations with its last reform. There are already some gaps detected in the statements. Even though the reformed policy requests that member states regulate their fishing practices, what is missing is a more specific and constraining guidance on appropriate national subsidies which would not enhance the capacity of their fleets (Self, 2015). Additionally, there is either no concrete direction to what degree environmental concerns should be implemented into the framework of fisheries management nor are the social aspects clearly defined (Prellezo and Curtin, 2015). According to Hatchard and Gray (2014), regional stakeholder-based fisheries governance is questionable and a common discourse between the EU institutions and member states is hardly achievable. Penas-Lado (2016) claims that proposals for CFP changes were significantly watered down and the policy remained static.

\section{Background of the Croatia's fisheries policy}

The Croatia's fisheries policy was a part of the Yugoslavian fisheries legislation until the 1990s. It consisted mainly of inefficient and periodical input support until 1965 (Bonačić-Mandinić, 1981). Little or no attention was given to structural measures with an emphasis on balanced and long-term sustainable fishing. In the period before 1976, Yugoslavian economic policy was more focused on other products in animal production, while fisheries products were marginalized both in government priorities and domestic consumption (Antolic, 1980). In the second half of 1970s and in the 1980s, Yugoslavian and Croatian governments created a new agro-industrial development plan with a greater emphasis on marine fisheries. It included an increase in fish farming and catches in the Adriatic Sea. The plan was sustained by agreements signed with foreign investors (Poland and New Zealand), but the final results did not follow the projected increase. A clear economic stimulus for investments in the industrial sector, modernization of fleet and catch were left out, and the agreement with foreign investors was not reached. Italian fishermen, Croatian fishermen's main competitors, had a favourable economic policy in the fisheries sector, which affected their advantageous position on the international market. The most important factors were: higher fish prices, lower prices of high quality fishing vessels, marine engines, fishing gear and fuel (Bonačić-Mandinić, 1981). Considering those differences, Italian fishermen were able to use marine resources more effectively and finally achieved a higher 
income. Additionally, Italian fishermen were also exploiting the territorial part of the Croatian Adriatic Sea, according to the agreement with the Yugoslavian Government, providing compensation fees (Klemenčić and Topalović, 2009). Those fees were not invested back into improving the Croatia's fisheries sector as intended. Another problem that had accumulated over the years was the quality of monitoring and keeping data records of all fisheries-related activities (fisheries technique, types of catches and their exploitation, food processing and other purposes, socio-economic indicators, price movements). Those data, if collected, were designated for different purposes but were not properly systematized or methodologically uniformed for a longer period, which represented a big issue for serious scientific analyses, especially in the field of biology (Dogan, 1974). In the 1990s, Croatia went through the transition period from planned to market economy after declaring independence. This period was marked with negative structural changes. The biological status of the Adriatic Sea was the same as in the European seas: excessive catch of undersized fish which caused overexploitation of fish and crabs, and degradation of habitat. Consequently, the processing industry faced an insufficient fish catch and increased demand, which negatively affected the production continuum and volume. In the 1990s, the fisheries production volume decreased by $58 \%$ as compared to the pre-War period (OG 89/2002). In order to create a basis for a fisheries policy, the Croatian Government adopted The Marine Fisheries Act in 1994 (OG 74/1994, 46/97, 48/05). It defined commercial fishing, noncommercial fishing and recreational fishing by commercial fishing license, fishing tools and fishing privileges, established a monitoring program of fish and marine organisms, and emphasized the necessity of declaring an exclusive economic fisheries zone. The support system, comprising marketprice measures, was a part of the Act on financial support in agriculture and fisheries (OG 46/97, 29/99). It supported only the catch of fish per kilo and fish processing products. Additionally, the Government supported the consumption of blue-coloured fuel (blue diesel) which both a legal and natural person, registered for fishing for economic purposes, could purchase without paying excise duties. The first official analysis of agriculture and fisheries in the independent Croatia was performed in 2002 and published in the document Strategy of the Government of the Republic of Croatia "Croatia in the 21st Century" (OG 89/2002). The Strategy presented the situation in the maritime sector, objectives and guidelines for the functioning of the public policy in the agricultural and fisheries sector. Many problems were detected and confirmed: a significant decrease in catch, constant presence of irresponsible catching practices, outdated technology and fisheries fleet, depletion of demersal species, increased presence of economically insignificant species, absence of developmental trends in mariculture, nonexistent measures of rational exploitation and protection of economically significant species, trade barriers during export, lack of favourable investment funds, inefficient fisheries inspection service, a disproportion between redemption and sale prices of fish conditioned by the existing situation and the lack of wholesale markets and auction sales, insufficient interest for joint actions and fishermen's organizations. Recommendations for fishing, mariculture, processing and distribution were based on prioritization, i.e. it was necessary to determine which species are of utmost economic importance. Furthermore, for a scientific approach to be taken during the assessment, systematization and supplementation of the fundamental bio-ecological features of the target species were suggested. The role of mariculture was promoted and the necessity was underlined to foster its modernization in the context of environmental sustainability, physical and social infrastructure improvement and diversification of products. The fisheries product market was an area marked by specific problems where the proposed solutions were: to create a wholesale market based on the auction principle, to establish fresh fish sale stations through direct deals or auctions and to implement structural changes by reducing the total number of subjects in the distribution chain.

\section{Croatian fisheries and EU membership}

Croatia applied for the EU membership in 2003 and started negotiations in 2005. During the pre-accession period, it was necessary to harmonize its legal system and regulatory framework with the acquis communautaire. This period was an opportunity for the Croatia's fisheries sector to adapt its goals, measures and stakeholders to achieve a more sustainable and internationally competitive fisheries sector in the future. The membership also facilitates commerce within the EU area, significant funding and technical assistance. Accordingly, a firm and concrete policy framework consisting of legal basis and operational documents is a prerequisite for a successful performance of the fisheries sector. The next Marine Fisheries Act (OG 56/10 and 55/11) repealed The Marine Fisheries Act from 1997. Besides regulating commercial, non-commercial and recreational fishing, it addressed the management, conservation and exploitation of fisheries resources, sea welfare, monitoring and reporting on biological quality and diversity, including aquaculture as part of the fisheries industry. The most important novelty in the national support system in comparison to the pre-accession period is the introduction of a structural support system with the Act on the Structural Support and Regulation of Markets in Fisheries (OG 153/09). Structural measures aimed at facilitating economic, environmental and social sustainability of the entire fisheries sector, enabling the appropriate standard of living of all subjects in fisheries, enabling a sustainable balance between the available resources and fishing capacity, strengthening the sector's 
competitiveness and encouraging equal representation and gender equality in the sector. For the first time this structural support act emphasized the importance of specifics pertaining to the local areas that should be taken into consideration while planning the implementation of certain structural measures. The Act was complemented with other important documents; firstly with the National strategic plan for development of fisheries (MA, 2013a) which sets out the priorities and goals of the fisheries development, and subsequently with the Operational programs for fisheries (MA, 2013b and MA, 2015). The operational programs encompass selected structural policy measures, a financial plan with annual amounts of aid and co-financing shares, the financing dynamics, an indication of the time period and institutions responsible for implementation. Structural measures were not entirely in line with the CFP. According to Mackelworth et al., 2011 the Croatian policy of state subsidies for fleet modernization is directly opposed to the CFP and the scientific advice of the General Fisheries Commission for the Mediterranean. The author states that Croatia has a fleet development program aimed at increasing the catch of the small pelagic species, while CFP subsidies for fleet modernization are directed to improving the crew safety, selective fishing techniques, quality of production and reducing fishing capacity. Several other maritime issues have marked the harmonization period and held up negotiations. Croatia declared an Ecological and Fisheries Protection Zone (EFPZ) in the Adriatic Sea (OG 157/03). It is an area of 23,870 square kilometres over which a state has exclusive rights regarding the exploration, research and use of marine resources as well as protection and conservation of the marine environment. This declaration stood in opposition to the fisheries chapter of the EU acquis which entrusts the management of a member state's fisheries, outside the $12 \mathrm{~nm}$ zone, to the CFP (Mackelworth et al., 2011). Due to the pressure from the EU and the opposition coming from Italy and Slovenia, in June 2004 Croatia delayed the implementation of the Zone to the European Union member states. Later on, in December 2006, it decided to fully implement the Zone starting from January 2008. Only two months thereafter, the Croatian Government decided not to enforce EFPZ for EU members. In addition, the sea dispute over the Gulf of Piran (Piran Bay) with Slovenia arose with the break-up of Yugoslavia. Despite the fact the United Nations Convention on the Law of the Sea from 1982 (UN, 1982) favours the median line, Slovenia claimed sovereignty over the entire bay asserting to be a disadvantaged State (Mackelworth et al., 2011). Since the bilateral agreement was not possible, the matter was handed to the international arbitration court. It ended this very year when the court ruled that Piran Bay belongs largely to Slovenia, which can thus have access to the open sea. Upon joining the EU, Croatia has accepted the EU's fishing policy and committed to apply the European rules on the implementation of fisheries control, categorization of fishermen, size and quantity of catches of certain species and features of the fishing gear (Reiter, 2015). In accordance with that, a new legislation framework came into force. Most importantly, the Marine Fisheries Act (OG 81/13, 14/14, 152/14) introduced considerably stricter rules on fishing, use of fishing gear and commerce of catches. It defined small-scale fishing as a special subcategory which had developed from the former category of subsistence fisheries for personal needs. The usage of commercial gear such as nets is not allowed in non-commercial fisheries, and therefore it was necessary to recognize the specific situation existing in Croatia and to find mechanisms for the transition from the former noncommercial category to a strictly limited sub-category of commercial fishing (MA, 2013a). The pelagic fisheries have a great socio-economic significance and are very important for the sustainability of rural coastal areas and remote island communities. They promote diverse ways of using resources, preserving traditional activities and nutrition. Currently, in the period 2014-2020, Croatia provides state aid to fisheries and receives assistance from the European Maritime and Fisheries Fund, with the EU and national budget amounting to a total of EUR 348,759,346.00, according to the latest Operational Program (OP) (MA, 2015). The main objectives of the OP are aimed at enhancing the sector's competitiveness, sustainability improvement and protection of natural resources and environment. To improve the overall position of the fisheries, Croatia uses subsidies to increase the added value of catches, to modernize the fishing infrastructure and support fishermen for temporary ceasing their activity. The Program also aims at improving the market organization of fisheries products by establishing the first producers' organizations in Croatia and by organizing promotional and communication campaigns (MA, 2015).

Unfortunately, the Program follows the pattern of the EU Directives which define the content of the document in accordance with the future CFP rather than presenting a clear picture of national priorities in fisheries. It is very important to separate commercial production from fishing as a lifestyle. In order to promote cooperation between the socio-economic and ecological elements of sustainable fisheries, it is important to respect local socio-ecological conditions and to involve local stakeholders in the decisionmaking process.

\section{Trend of macroeconomic indicators and impact of the support system}

Croatian fisheries contribute to the Gross Domestic Product (GDP) with a share of $0.2-0.7 \%$ which is relatively low considering that the Croatian Adriatic Sea is one of the 
main comparative advantages in the international context (Vlahinić et al., 2006; Reiter, 2015), covering 35.5\% of Croatian territory. In estimating the share of fisheries in GDP, it is necessary to include the construction and servicing of vessels, production of tools and equipment, transportation, warehousing and related logistics, harbour activities related to fishing and, to some extent, certain forms of tourism (MA, 2013a). Furthermore, what should be included in general assessments of the importance of the fisheries sector is the supply of high-quality food, positive external trade balance and importance of employment on the coast and islands where fishing is one of the few activities that provide the source of income throughout the year (MA, 2013a). Since 2013, the Croatia's fisheries sector has been registering a significant increase in production value (Table 1 ). This is due to an increase in the value of maritime fishing which included a mild increase both in quantity sold and prices. The price of carp, which has the highest share in the value of freshwater fishing products, increased by $28 \%$ but its quantity sold decreased by $20.7 \%$ in 2016 (CBS, 2017). Consequently, production value did not meet the expected growth in 2016. To achieve a higher added value of production and consequently a higher price, one should adapt the product to the demands of the market and follow its trends. Higher price could be achieved by production innovation and product processing, using quality brand labels or ecolabels.

Trade balance in the Croatia's fisheries sector is deemed positive in the observed period, which means that the value of export is consistently higher than the import value. The most important export products are bluefin tuna, anchovy, canned sardines and fresh sea bass from breeding. Croatia imports significant quantities of relatively cheap products and exports high-quality products (MA, 2013). The number of fishermen is significantly growing, mostly due to the shift from the category of small fishing (fishing for personal needs) to commercial fishing (small coastal fishing). Unfortunately, the most common quality of life indicator - income shows that fishermen's average income per month is significantly below the average salary. It can be noted that budget support in the fisheries has increased by $254 \%$ in 2016, as compared to 2007 (Table 1).

Market-price support significantly dominates the budget. It implies support for production and processing of fisheries products and market compensation to fishing cooperatives or individual licensed fishermen for the amount of sold sea fish and marine organisms (Fig. 1). A

Table 1. . Main Croatian macroeconomic indicators of the fisheries sector in the period 2007-2016

\begin{tabular}{|c|c|c|c|c|c|c|c|c|c|c|}
\hline & 2007 & 2008 & 2009 & 2010 & 2011 & 2012 & 2013 & 2014 & 2015 & 2016 \\
\hline $\begin{array}{l}\text { Catches } \\
\text {-in } 000 \text { tons }\end{array}$ & 48.63 & 49.01 & 55.37 & 52.40 & 70.53 & 63.60 & 75.27 & 78.93 & 72.27 & 71.86 \\
\hline Fishing fleet & 3,716 & 3,718 & 3,886 & 4,029 & 4,136 & 4,259 & 4,329 & 7,384 & 7,849 & 7,746 \\
\hline Number of fishermen & 3,748 & 3,740 & 3,886 & 3,995 & 3,564 & 3,322 & 3,535 & 7,733 & 7,849 & 7,746 \\
\hline $\begin{array}{l}\text { Average income } \\
\text {-in HRK }\end{array}$ & 3,895 & 3,978 & 4,256 & 4,264 & 4,366 & 4,623 & 4,834 & 4,876 & 4,723 & 4,825 \\
\hline $\begin{array}{l}\text { Value of production } \\
\text {-in mln HRK }\end{array}$ & 314.53 & 391.00 & 338.41 & 278.52 & 315.56 & 743.07 & 707.12 & 884.47 & $1,144.82$ & $1,126.61$ \\
\hline $\begin{array}{l}\text { Export } \\
\text {-in mln HRK }\end{array}$ & 702.54 & 612.14 & 713.50 & 621.72 & 815.42 & 743.07 & 707.12 & 884.47 & $1,144.82$ & $1,126.61$ \\
\hline $\begin{array}{l}\text { Import } \\
\text {-in mln HRK }\end{array}$ & 528.95 & 557.83 & 419.51 & 431.08 & 527.64 & 532.44 & 479.01 & 562.85 & 688.32 & 750.20 \\
\hline $\begin{array}{l}\text { Trade balance } \\
\text {-in mln HRK }\end{array}$ & 173.59 & 54.30 & 293.99 & 190.64 & 287.78 & 210.64 & 228.10 & 321.63 & 456.50 & 376.41 \\
\hline $\begin{array}{l}\text { Total budget support } \\
\text {-in mln HRK }\end{array}$ & 151.45 & 219.62 & 207.09 & 191.63 & 243.75 & 283.49 & 316.05 & 204.79 & 256.98 & 383.77 \\
\hline Exchange rate 1 EUR=HRK & 7,34 & 7,22 & 7,34 & 7,29 & 7,43 & 7,52 & 7,57 & 7,63 & 7,61 & 7,53 \\
\hline
\end{tabular}

Sources: CBS, Eurostat, DF, PAAFRD, various years 
highly important market-price measure is tax-exempt blue diesel, representing the largest individual expense (50-60\%) in the business activity of the economic entities engaged in marine fishing. Since 2010, the data on the sold quantity of tax-free blue diesel is officially gathered by the DF. Its average share in the total market-price support is ca. $40 \%$, and $30 \%$ in the total budget support. Structural support implies sustainable development of fisheries and aquaculture areas. It supports fishermen in their complying with permanent or temporary cessation, maintenance of the ponds ecosystem, new safety measures and changes to working conditions, fisheries associations, investments in aquaculture, data collection and port infrastructure. Fig. 1 shows that structural support began to increase its share in the total fisheries support due to the new direction of national fisheries policy which was in the process of harmonization with the CFP. In 2014, Croatia started implementing the Operational Program for Maritime Affairs and Fisheries of the Republic of Croatia for 2014-2020 (MA, 2015). A significant increase in activities was noted in 2015 and 2016, especially for permanent and temporary cessation of fishing vessels. This measure contributes to sustainability and rebalancing of fishing capacity with fishing resources. Capacity building support implies administrative or educational financial measures which provide improvements in the infrastructure and skills due to the CFP requirements.

\section{CONCLUSION}

Discourse analysis demonstrated that the CFP framework has drastically changed since it was first enacted in 1983. The focus has been shifted from preservation of free-access fishing practices in the EU common waters and regulation of common market to contemporary biological concerns stemming from the overexploitation and depletion of fisheries resources. From 1993 until the present day, there have been three reforms of the CFP, each one attempting to create a framework to repair or mitigate the following structural failures: fleet overcapacity, lack of conservation measures and scientific recommendations to protect stocks, imprecise policy objectives resulting in insufficient guidance for decisions, negative socio-economic consequences due to management changes, lack of stakeholders' involvement in the decisionmaking process and increase in the complexity of rules. The last reform in 2013 defined new priorities and tailored funds to promote an integrated approach in the CFP, which means sustainable, resource efficient, innovative, competitive and knowledge-based fisheries and aquaculture, increase of territorial cohesion and encouragement of marketing and processing. Croatian fisheries under the Yugoslavian legislation did not receive proper attention, especially in the context of balanced and long-term sustainable fishing. After the independence, the Government's sectoral analysis

\section{Structure of support to fisheries}

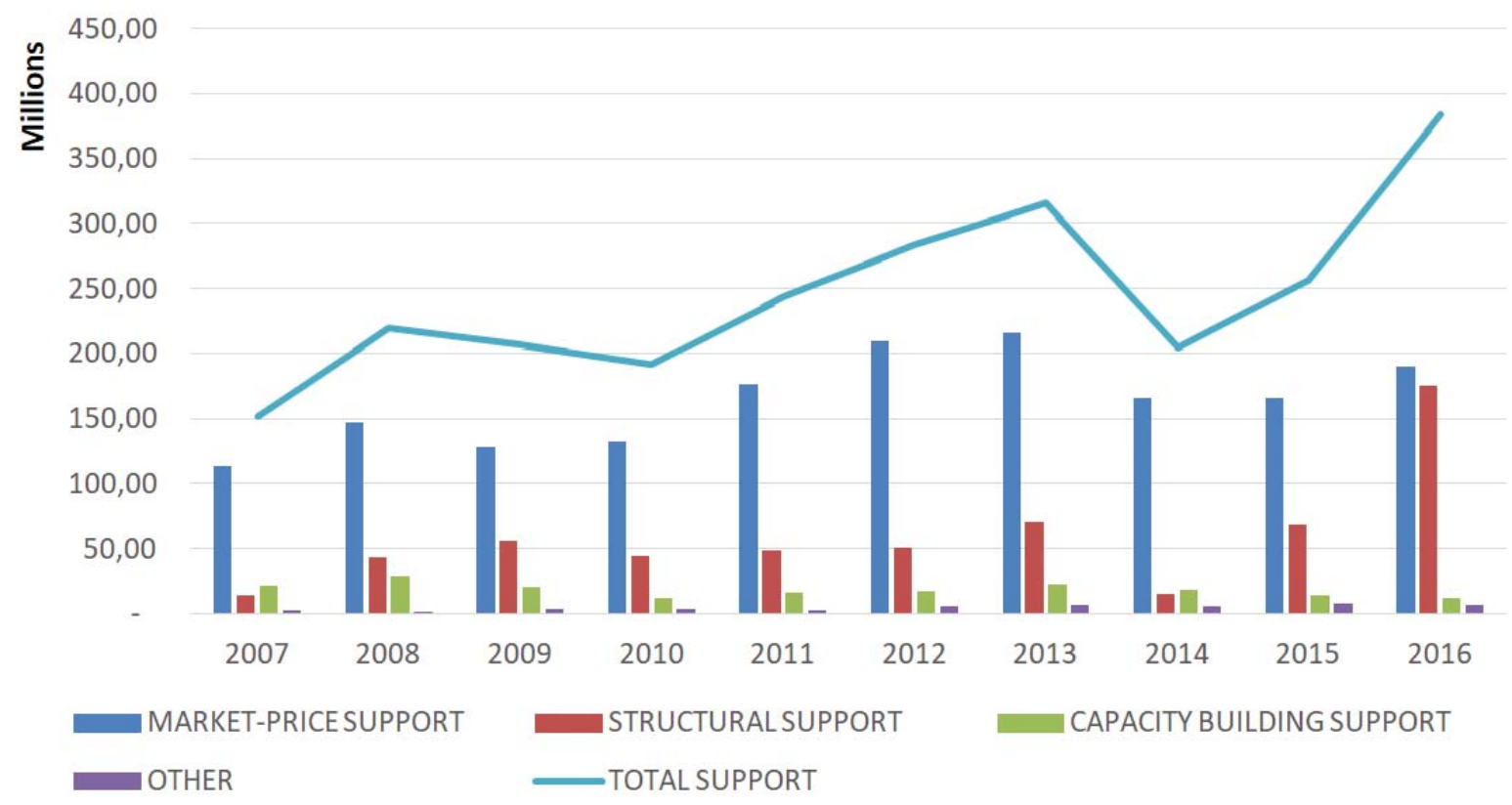

Fig 1. Structure of Croatian budgetary support to fisheries 2007-2016

Source: Authors' calculation based on PAAFRD and MF, various years 
showed a serious decrease of catches, irresponsible catching practices, outdated technology and fisheries fleet, absence of investments and developmental trends in mariculture, inefficient fisheries inspection service, poor market and insufficient interest in fishermen's organizations. The most important novelty in the period of harmonization with the EU CFP framework was the introduction of a structural support system which aimed at facilitating the economic, environmental and social sustainability of the entire fisheries sector. Macroeconomic indicators show a significant importance of the fisheries sector in the Croatian economy (GDP share, positive trade balance, increasing value of the sector). The budget increase for structural measures during 2007-2016 confirms the process of acceptance of the new CFP, which gives greater importance to the integrated approach in resolving the fisheries-related issues.

\section{SAŽETAK}

\section{ZAJEDNIČKA RIBARSTVENA POLITIKA I NJEZIN UTJECAJ NA HRVATSKI SEKTOR RIBARSTVA}

Ciljevi ovog rada su: 1) odrediti ključne promjene u procesu razvoja Zajedničke ribarstvene politike EU (ZRP) i hrvatske ribarstvene politike te 2 ) opisati strukturu i dinamiku kretanja makroekonomskih i proračunskih pokazatelja vezanih uz hrvatsko ribarstvo u razdoblju 2007.-2016. U radu je korištena povijesna metoda i deskriptivna analiza makroekonomskog stanja i strukture proračuna. ZRP je službeno uveden 1983. godine s namjerom da predstavlja zajednički sustav upravljanja ribarstvom u ime svih zemalja članica. Ciljevi ZRP-a bili su: riješiti konflikte zemalja članica na morima, osigurati stabilnost sektora ribarstva, spriječiti totalno uništenje ribljih stokova i osigurati ribarima bolju kvalitetu života. Međutim, ZRP je redovito na meti kritika zbog nedovoljne primjene okolišnih mjera i znanstvenih sugestija kao i zbog nedostatka zajedničkog dijaloga između institucija EU i lokalnih dionika razvoja. Kako u EU, tako se i u Hrvatskoj sektor ribarstva suočio s mnogo problema, a osobito devedesetih godina prošlog stoljeća, u vrijeme tranzicije. Neki od njih bili su ozbiljni pad ulova, zastarjela tehnologija i ribarska flota, osiromašenje podmorja, nedostatak razvojnih trendova u marikulturi, nedostatak mjera za razumno iskorištavanje $\mathrm{i}$ zaštitu pojedinih vrsta većeg ekonomskog značaja. Razdoblje pregovora za ulazak u EU predstavljalo je ujedno i priliku da hrvatski sektor ribarstva prilagodi svoje ciljeve, mjere i dionike u svrhu dostizanja održivog i međunarodno konkurentnog sektora u budućnosti. Također, članstvo olakšava trgovinu unutar EU zone i značajnu financijsku i tehničku podršku. Struktura potpora iz proračuna i postojeća politika naglašavaju povećanje primjene strukturnih mjera koje bi trebale doprinijeti poboljšanju društvenih, gospodarskih i okolišnih elemenata u ribarstvu.
Ključne riječi: Hrvatska, EU, ribarstvena politika, proračun za ribarstvo, makroekonomski pokazatelji

\section{REFERENCES}

Antolić, B. (1980): Razvojne tendencije morskog ribarstva Jugoslavije. Fakultet poljoprivrednih znanosti Sveučilišta u Zagrebu. Diplomski rad obranjen 9. svibnja 1980. (in Croatian)

Barclay, C. (1996): The EU Common Fisheries Policy. House of Commons Library Research Paper. 96/6. Available from: http://researchbriefings.parliament.uk/ResearchBriefing/ Summary/RP96-6

Bonačić-Mandinić, M. (1981): Ekonomski položaj morskog ribarstva u Jugoslaviji. Fakultet poljoprivrednih znanosti Sveučilišta u Zagrebu. Diplomski rad obranjen 11. studenoga 1981. (in Croatian)

Caddy, J. F. (1998): Fisheries management in the twenty-first century: will new paradigms apply? Reviews in Fish Biology and Fisheries, 9, 1-43.

CBS (2017): Fishery, 2016. First release number 1.4.1. from 7 July, 2017

Churchill, R. (1987): EEC Fisheries Law. Springer Netherlands. 299 pp.

Dogan, K. (1974): State and some problems of fisheries statistics. Acta Adriatica, 16, 3, 68-70.

European Commission - EC (1957): The Treaty of Rome. https://ec.europa.eu/romania/sites/romania/files/tratatul_de_la_roma.pdf Accession: 27. 2. 2017.

European Commission - EC (2001): Green Paper on the Future of the Common Fisheries Policy. 20. 3. 2001., Brussels http://eur-lex.europa.eu/legal-content/EN/TXT/PDF/?uri =CELEX:52001DC0135\&from=EN. Accession: 27. 2. 2017.

Committee on Fisheries Secretariat (2009): Information Kit. July 2009, Brussels http://www.europarl.europa.eu/document/activities/cont/200907/20090720ATT58574/20 090720ATT58574EN.pdf Accession: 27. 2. 2017.

Gray, T., Hatchard, J. (2003): The 2002 reform of the Common Fisheries Policy's system of Governance - rhetoric or reality? Marine Policy, 27, 6, 545 - 554.

Hatchard, J., Gray, T. (2014): From RACs to Advisory Councils: Lessons from North Sea discourse for the 2014 reform of the European Common Fisheries Policy. Marine Policy, 47, $87-93$.

Klemenčić, M., Topalović, D. (2009): The maritime boundaries of the Adriatic Sea. Geoadria, 14, 2, 311 - 324.

Lynge, J. C. (1999): A Critical Review of the Common Fisheries Policy. Working Paper, Department of Environmental and Business Economics, University of Southern Denmark. Available from: https://www.econstor.eu/handle/10419/83121

Mackelworth, P., Holcer, D., Jovanović, J., Fortuna, C. (2011): Marine Conservation and Accession: The Future for the Croatian Adriatic. Environmental Management, 47, 4, 644-655. 
Markus, T. (2010): Towards sustainable fisheries subsidies: Entering a new round of reform under the Common Fisheries Policy. Marine Policy, 34, 6, 1117-1124.

Ministry of Agriculture - MA (2013a): National strategic plan for development of fisheries. Available from: http:// www.mps.hr/ribarstvo/default.aspx?id=490

Ministry of Agriculture - MA (2013b): Operational programme for fisheries of the Republic of Croatia for the programming period 2007-2013, Available from: http:// www.mps.hr/ribarstvo/default.aspx?id=489

Ministry of Agriculture - MA (2015): Operativni program za pomorstvo i ribarstvo Republike Hrvatske za programsko razdoblje 2014.-2020. Available from: http://www.mps. $\mathrm{hr} /$ ribarstvo/default.aspx?id=551 (on Croatian)

OG (1994): Zakon o morskom ribarstvu. no. 74, 18. 4. 1994.https:// narodne-novine.nn.hr/clanci/sluzbeni/1994_10_74_1289.html. Accession: 27. 2. 2017.

OG (1997): Zakon o morskom ribarstvu. no. 46, 5. 5. 1997.https://narodne-novine.nn.hr/clanci/sluzbeni/1997_05_46_670.html . Accession: 27. 2. 2017.

OG (1997): Zakon o novčanim poticajima u poljoprivredi i ribarstvu. no. 46, 5. 5. 1997. https://narodne-novine. nn.hr/clanci/sluzbeni/1997_05_46_670.html Accession: 27. 2. 2017.

OG (1999): Zakon o novčanim poticajima i naknadama u poljoprivredi i ribarstvu. no. 29, 26. 3. 1999. https://narodnenovine.nn.hr/clanci/sluzbeni/1999_03_29_582.html. Accession: 27. 2. 2017.

OG (2002): Strategija poljoprivrede i ribarstva Republike Hrvatske. no. 89, 25. 7. 2002. https://narodne-novine. nn.hr/clanci/sluzbeni/2002_07_89_1471.html Accession: 27. 2. 2017.

OG (2005): Zakon o izmjenama i dopunama Zakona o morskom ribarstvu. no. 48, 13. 4. 2005. https://narodnenovine.nn.hr/clanci/sluzbeni/2005_04_48_933.html. Accession: 27. 2. 2017.

OG (2009): Zakon o strukturnoj potpori i uređenju tržišta u ribarstvu. no. 153, 21. 12. 2009. https://narodne-novine. nn.hr/clanci/sluzbeni/2009_12_153_3747.html. Accession: 27. 2. 2017.

OG (2010): Zakon o morskom ribarstvu. no. 56, 7. 5. 2010.https://narodne-novine.nn.hr/clanci/sluzbeni/2010_05_56_1341.html. Accession: 27. 2. 2018.

OG (2011): Zakon izmjeni i dopuni Zakona o morskom ribarstvu. no. 55, 18. 5. 2011. https://narodne-novine. nn.hr/clanci/sluzbeni/2011_05_55_1203.html. Accession: 27. 2. 2017.

OG (2003): Odluka o proširenju jurisdikcije Republike Hrvatske na Jadranskom moru. no. 157, 6. 10. 2003.https://narodne-novine.nn.hr/clanci/sluzbeni/2003_10_157_2250.html. Accession: 27. 2. 2017.

OG (2013): Zakon o morskom ribarstvu. no. 81, 29. 6. 2013.https://narodne-novine.nn.hr/clanci/sluzbeni/2013_06_81_1702.html. Accession: 27. 2. 2017.
OG (2014): Zakon o izmjenama Zakona o morskom ribarstvu. no. 14, 5. 2. 2014. https://narodne-novine.nn.hr/ clanci/sluzbeni/2014_02_14_280.html. Accession: 27. 2. 2018.

OG (2014): Zakon o izmjenama i dopunama Zakona o morskom ribarstvu. no. 152, 22. 12. 2014. https://narodnenovine.nn.hr/clanci/sluzbeni/2014_12_152_2871.html. Accession: 27. 2. 2017.

OJ (1970): Regulation (EEC) of the Council laying down a common structural policy for the fishing industry. no 2141, of 20 October 1970. http://eur-lex.europa.eu/ legal-content/EN/TXT/PDF/?uri=CELEX:31970R2141\&fr om=EN Accession: 27. 2. 2017.

Pastoors, M. A. (2014): Exponential growth in the number of words used for the European Common Fisheries Policy(CFP): Does better management require more text? Marine Policy, 46, 101 - 104.

Prellezo, R., Curtin, R. (2015): Confronting the implementation of marine ecosystem-based management within the Common Fisheries Policy reform. Ocean \& Coastal Management, 117, 43 - 51.

Penas-Lado, E. (2016): The Common Fisheries Policy: The Quest for Sustainability. Chichester, West Sussex, Wiley Blackwell. 390.

Schweiger, L. (2010): The Evolution of the Common Fisheries Policy: Governance of a Common-Pool Resource in the Context of European Integration. Working Paper No. 07/2010. Institute for European Integration Research, Vienna, Austria

Self, E. (2015): Who Speaks for the Fish? The Tragedy of Europe's Common Fisheries Policy Vanderbilt Journal of Transnational Law. 48, 2, 577-607.

Suris-Regueiro, J. C., Varela-Lafuente, M. M., Garza-Gil, M. D. (2011): Evolution and Perspectives of the Fisheries Structural Policy in the European Union. Ocean \& Coastal Management, 54, 8, 593-600

Symes, D. (1997): The European Community's Common Fisheries Policy. Ocean \& Coastal Management, 35, 2-3, 137-155.

Reiter, S. (2015): The Role of Fisheries in Coastal Zone Management - Case of Croatia. Naše more, 62, 4, 127-133.

United Nations - UN (1982): United Nations Convention on the Law of the Sea. Available from: http://www.un.org/ depts/los/convention_agreements/convention_overview_convention.htm

Vlahinić-Dizdarević, N., Negovetić, M. (2006): Mjere ekonomske politike u funkciji poticanja morskog ribarstva Republike Hrvatske. Economic research - Ekonomska istraživanja, 19, 1, 65-77. (in Croatian)

Walter, T. (2010): The EU's Common Fisheries Policy: A review and assessment. European Union Miami Analysis (EUMA), Special Series, 7, 7, 9 pp. Available from: http:// aei.pitt.edu/29777/1/WalterFisheries2010EUMAedi.pdf 